\title{
ASSESSING AGRO-CLIMATIC INDICES, PRODUCTIVITY AND PROFITABILITY OF LATE PLANTED CHICKPEA THROUGH CLIMATE CHANGE ADAPTATION MEASURES IN MADI, CHITWAN
}

\author{
L.P. Amgain ${ }^{1}$ and U. Dhakal ${ }^{2}$
}

\begin{abstract}
To assess the agro-climatic indices, crop productivity and profitability of late planted chickpea (Cicer arietinum L.) through climate change adaptation measures; a field experiment was accomplished on the farmer's field in Madi, Chitwan from December 2015 to April 2016. In estimation of agro-climatic indices, the highest growing degree days and stable heat use efficiency were recorded for Dhanush and ICL 840508-41 cultivars with NPK and mulching. The results exerted that seed yield of chickpea obtained with ICL-840508-41 under NPK (1052 kg ha-1) was significantly superior to the seed yield obtained with FYM $\left(915.0 \mathrm{~kg} \mathrm{ha}^{-1}\right)$. Similarly, the higher seed yield of chickpea was recorded under NPK with mulch $\left(1023.0 \mathrm{~kg} \mathrm{ha}^{-1}\right)$. The application of NPK exhibited significantly higher returns and $B: C$ ratio than that of $F Y M$. Therefore, it is suggested that improved cultivar of chickpea, balanced fertilization through NPK and mulching would be the productive and profitable climate change adaptation measures for chickpea under delayed planting in inner-terai and terai regions of Nepal.
\end{abstract}

Key words: Agro-climatic indices, chickpea, climate change adaptation measures, productivity, profitability

\section{INTRODUCTION}

Chickpea (Cicer arietinum L.) is an important food legume ranking third among the world's pulse crops and a major pulse grown in Nepal as the primary protein source for nearly two million Nepalese people (Pokhrel et al., 2018). The area under cultivation of chickpea in Nepal is about 17005 ha, with the production and productivity only of $9380 \mathrm{t}$ and $0.55 \mathrm{t} \mathrm{ha}^{-1}$, respectively (MoAD, 2014). Chickpea is grown in warm valleys and river basins in hills as rainfed crops, but the late planting of chickpea is a common practice in the long-duration rice grown belts of Nepalese terai (NGLRP, 2018). As described by Summer field et al., (1989) and Reddy and Reddi (2009), the staple cereal crops yield higher due to greater net assimilation rate (NAR= Photosynthesis - respiration), whereas energy protective legume crops yield low due to higher energy

1 Assoc. Prof. Agronomy, IAAS Rampur Campus, Khariahani, Chitwan

Corresponding author: Email:amgainlp@gmail.com

2 Post-graduate student, Agronomy, IAAS 
(ECE $=$ Photosynthesis/respiration). It is generally reported that a gram of photosynthate is equivalent to $0.75-0.84$ gram of carbohydrate in cereals, 0.38 0.41 gram of amino-acid in legumes and $0.31-0.33$ gram of fatty-acid in oilseed crops in forming the energy output (Ghosh et al., 2000; Reddy and Reddi, 2009).

Climate change and agriculture are interrelated processes, both of which take place on a global scale (Hoffmann, 2013) showing a complex problem to the world from the very earlier (FAO, 2015; Pathak et al., 2002). It has been observed that changes in the seasonal temperature and rainfall patterns and their subsequent impact on yield may change geographical distribution of chickpea production (Daniel, 2015). Chickpea being a winter crop,adverse weather factor greatly reduces its productivity, as its early sowing around October- November 15 may not always result in higher yields despite earlier flowering because of the increased risk of insect pests and diseases attacks, and higher pollen mortality (Khanna et al., 1987) due tovery less temperatures coinciding at flowering and fruit setting. Under this circumstance, chickpea yield can also be compensated under delayed planting upto late December through short vegetative and flowering phases due to conducive temperature to subsequent pod development (NGLRP, 2015; Gill and Ahalwat, 2006; Rathore et al., 1998). Hence, the adaptation of new technologies and increased productivity of chickpea is often limited by low and high temperatures at its various pheno-phases because temperature is a major environmental factor regulating the timing of chickpea flowering and fruiting, thus influencing seed yield.

Conservation tillage practice (zero-tillage + mulching + crop diversification) is a viable approach to retain soil moisture and nutrients under rainfed situations because the use of organic materials as mulch is considered poor conductor of heat that effectively moderate soil temperature, maintain soil moisture, and increase soil fertility (Vaidya et al., 1995). Growing drought resistant varieties, balanced fertilization and application of organic manuring, farm yard manure (FYM), and crop residues management are suggested the best climate change adaptive strategies practiced globally (Lal et al., 2004; Amgain, 2013). Mulching has generally been practiced with a view to maintain soil permeability, prevent soil erosion, reduce evaporation, and manage weed flora, adapting climate change measures, and to increase crop yield. There are several records of using the prunings of various trees and shrubs grown in noncropped alley lands as brought-in mulch since pre-historic time as in the Vedas and Kuran, and it is still dominant in highland and rainfed areas of hindu-kush Himalayas (Dhyani et al., 2009). Agriculture in Nepal is based on subsistence 
farming with crops, livestock and trees forming integral part of the indigenous agro-forestry based farming system. New technology, management practices and improved methods and materials on lately planted rainfed chickpea cultivation have not yet made roads into the Nepalese farming community. Legumes like chickpea are also considered the best crops to moderate the soil fertility and crop productivity. Chickpea cultivars are broadly of two types, Dhanush as Deshiand ICL-840508-41 as Kabulian types, and both are grown dominantly in Nepal as climate change adaptive varieties (NGLRP, 2015). So far this study was planned and executed for assessing the ways to augment the growth, productivity and profitability of late planted chickpea through a congenial climate change adaptation measures at Riu water basin of Madi, Chitwan.

\section{MATERIALS AND METHODS}

The on-farm field experiment was planned and executed in the farmers' field of Riu water basin at Basantapur, Madi, towards $40 \mathrm{~km}$ south-west $\left(27.29^{\circ} \mathrm{N}\right.$, $84.52^{\circ} \mathrm{E} 256$ masl.) from Bharatpur, headquarter of Chitwan district from December 2015 to April, 2016 (NMRP, 2015). The soil of the experimental plot was found to be loamy sand in texture with slightly acidic $\mathrm{pH}(6.3)$, low in total nitrogen $(0.014 \%)$ and soil available potassium $\left(105.2 \mathrm{~kg} \mathrm{ha}^{-1}\right)$, while medium in soil available phosphorous $\left(29.5 \mathrm{~kg} \mathrm{ha}^{-1}\right)$ and soil organic matter $(2.84 \%)$. The area resembled pretty cool weather during the chickpea growing period with total of $14.8 \mathrm{~mm}$ rainfall.

The experiment was laid out in strip-split plot design with three replications. In the columns, chickpea cultivars: $\mathrm{V}_{1}-\mathrm{KWR}-108$ (Kabulian type; drought semihardy, $\mathrm{V}_{2}$-Dhanush (Deshi type; Local check), and $\mathrm{V}_{3}$-ICL-840508-41 (Kabuliant ype; drought hardy) were placed with nutrient management practices in rows: $\mathrm{F}_{1}$-FYM @ 5.0 ha $^{-1}$ and, $F_{2}$-recommended NPK (20:40:30 kg NPK ha-1 $)$. In subplots, two level of mulching: $M_{0}-$ no mulching (control mulch) and $M_{1}$-paddy straw mulching $\left(5.0 \mathrm{t} \mathrm{ha}^{-1}\right)$ were tested. The plots were ploughed once by tractor followed by 2-3 diggings and removal of the weeds was done before 2 days of planting. Nitrogen, phosphorus and potash were applied in rows at the rate of 20, 40 and $30 \mathrm{~kg} \mathrm{ha}^{-1}$ through Urea, Diammonium phosphate (DAP) and Muriate of Potash (MOP) as per treatments.

Chickpea cultivars (KWR-108, Dhanush and ICL-840508-41) were seeded manually with inter and intra row spacing of $30 \mathrm{~cm}$ and $10 \mathrm{~cm}$, respectively with the seed rate of $40 \mathrm{~kg} \mathrm{ha}^{-1}$. Shallow furrow was made with spade in which DAP, Urea and MOP was mixed and chickpea seed was continuously placed on the same day. Seeds sown on plots in each column were covered by paddy straw 
mulch @ $5.0 \mathrm{t} \mathrm{ha}^{-1}$ and the next split plot was kept without mulch as per the splitting of the treatments. Since experiment was conducted in rainfed condition, no any irrigation was given, however, supplemental irrigation of about $2 \mathrm{~mm}$ through water cane was provided once for the better germination of the crops at 10 days after sowing (DAS). Insecticide Cypermethrin @ $2 \mathrm{ml}$ mixed in 1.0 liter of water was applied as plant protection measure to control the Helicoverpa borer at 60 DAS. The crop from net plot area was harvested with the help of the sickle manually at its physiological maturity stage. Harvested plants were left in the field for 3 days for sun drying. Threshing was done manually after sun drying of harvested crop and seeds were cleaned by winnowing.

Ten plants of chickpea in each plot were selected randomly, marked, fixed tagged and regularly observed to notify the phenological stages $(75 \%$ anthesis and physiological maturity). Theagro-climatic indices were calculated as accumulated heat unit system (Rajput et al., 1987 and Bishnoiet al., 1995).The various measurements of accumulated heat units were calculated according to the following formulae (Ritchie and Nesmith, 1991).

1. Growing degree days $(G D D)=\Sigma\left[(T \max +T \min ) / 2-T_{b}\right]$

[Base temperature $\left(T_{b}\right)=4^{\circ} \mathrm{C}$; Source: Rajput, 1980]

2. Heat use efficiency $(\mathrm{HUE})=$ Grain yield $\left(\mathrm{kg} \mathrm{ha}^{-1}\right) \div \mathrm{GDD}$

3. Pheno-thermal index $(\mathrm{PTI})=\mathrm{GDD} \div$ Growth days

Yield attributes like number of the pods branch ${ }^{-1}$ and seeds pod ${ }^{-1}$ were taken from the five plants of the net plot area of each plot by random selection just before the harvesting of the crop and mean was calculated. In total, twenty pods were selected to count the number of seeds pod ${ }^{-1}$.Observation regarding seed and stalk yields were selected from the $6.25 \mathrm{~m}^{2}$ net plot area and the seed yield hectare ${ }^{-1}$ was computed for each treatment. Digital moisture meter was used to record the moisture percentage of the chickpea seed to adjust the seed moisture at $12 \%$ using the formula as suggested by Paudel (1995). Harvest index $(\mathrm{HI})$ was computed by dividing grain yield with the total dry matter yield. Total cost of cultivation of chickpea has been added by the fixed and variable costs of cultivation of chickpea, assumed fixed for all three replications as per treatments, while economic yield was converted into gross returns in Nepalese currency (NRs ha-1) on the basis of local market price of seed and stalk yields of chickpea (Dhakal, 2013). The chickpea seeds were sold in the price of NRs $120 \mathrm{~kg}^{-1}$ and stalk yield in NRs $3 \mathrm{~kg}^{-1}$ in calculating the gross returns. Net return was calculated by subtracting the cost of cultivation from the gross returns of the individual treatment. Benefit: cost ratio was expressed as net returns per 
rupee invested. All the data obtained from research was analyzed using MSExcel and MSTAT-C (Version 1.3, Michigan University, 1994). Analysis of variance (ANOVA) was performed to analyze differences between different experimental treatments at the 0.05 probability level and DMRT was performed for mean comparison at the 0.05 level of significance. All results presented in this study are at the $p<0.05$ levels (Gomez and Gomez, 1984).

\section{RESULTS AND DISCUSSION}

\section{CALENDAR DAYS AND AGRO-CLIMATIC INDICES OF VARIOUS CHICKPEA CULTIVARS}

The interaction effect of cultivars, manuring and mulching on agro-climatic indices of chickpea showed the significant result only for degree days and heat use efficiency (Table 1). Though it is variable, the effect on physiological maturity and pheno-thermal index were found to be non-significant. Days to maturity were higher in the application of mulch, but it was found to be nonsignificant. The growing degree days showed that days for the attainment of phenological stages differed from cultivar to cultivar and mulching, but manuring has not such a prominent effect. The highest heat unit requirement was seen in Dhanush and ICL-840508-41 cultivars $\left(1810\right.$ to $\left.1811.6^{\circ} \mathrm{C}\right)$ with NPK fertilizer on applying mulch. Under delayed planting condition of this trial, the chickpea did not show any negative effect on crop duration and phenology under the fluctuated temperature and sunshine hours associated with stable average temperature and less foggy days observed during the crop periods. The heat use efficiency of chickpea was higher and stable $(0.68)$ with the application of mulch on ICL 840508-41 cultivar under NPK fertilizer followed by other treatments indicating the superiority of the mulching with drought tolerant variety than the Dhanush and KWR-108. The seed yield of chickpea and heat use efficiency were found to be followed in the same trend. This result was due to more accumulation of dry matter and more photosynthate metabolized as a result of congenial values of average ambient temperature due to more clear days (Sreenevas et al., 2010; Sikder, 2009; Ghosh et al., 2000). All the cultivars had shown lesser pheno-thermal index (PTI) under no mulch condition, however, higher pheno-thermal index was recorded due to the application of mulch. 
The Journal of Agriculture and Environment Volume: 20, June, 2019

Table 1: Influenced of mulch and nutrients on agro-climatic indices (GDD) of chickpea

\begin{tabular}{llllll}
\hline \multirow{2}{*}{ Treatment } & \multicolumn{5}{c}{ Agro- climatic indices } \\
\cline { 2 - 6 } & $\begin{array}{c}\text { Calendar days } \\
\text { to physiological } \\
\text { maturity }\end{array}$ & $\begin{array}{c}\text { Growing } \\
\text { Degree } \\
\text { Days }\left({ }^{\circ} \mathrm{C}\right)\end{array}$ & $\begin{array}{c}\text { Grain } \\
\text { yield } \\
\left(\mathbf{k g ~ h a}^{-1}\right)\end{array}$ & $\begin{array}{c}\text { Heat Use } \\
\text { Efficiency } \\
\text { (HUE) }\end{array}$ & $\begin{array}{c}\text { Pheno- } \\
\text { thermal } \\
\text { Index (PTI) }\end{array}$ \\
\hline $\mathrm{V}_{1} \mathrm{~F}_{1} \mathrm{M}_{0}$ & 111 & 1655.7 & 350.0 & 0.22 & 14.87 \\
$\mathrm{~V}_{1} \mathrm{~F}_{1} \mathrm{M}_{1}$ & 111 & 1671.6 & 416.7 & 0.25 & 14.92 \\
$\mathrm{~V}_{1} \mathrm{~F}_{2} \mathrm{M}_{0}$ & 116 & 1705.9 & 346.7 & 0.21 & 15.05 \\
$\mathrm{~V}_{1} \mathrm{~F}_{2} \mathrm{M}_{1}$ & 115 & 1740.1 & 683.3 & 0.39 & 15.17 \\
$\mathrm{~V}_{2} \mathrm{~F}_{1} \mathrm{M}_{0}$ & 116 & 1766.3 & 500.0 & 0.28 & 15.27 \\
$\mathrm{~V}_{2} \mathrm{~F}_{1} \mathrm{M}_{1}$ & 116 & 1774.7 & 700.0 & 0.39 & 15.30 \\
$\mathrm{~V}_{2} \mathrm{~F}_{2} \mathrm{M}_{0}$ & 117 & 1792.2 & 853.3 & 0.48 & 15.36 \\
$\mathrm{~V}_{2} \mathrm{~F}_{2} \mathrm{M}_{1}$ & 117 & 1811.6 & 1016.7 & 0.64 & 15.43 \\
$\mathrm{~V}_{3} \mathrm{~F}_{1} \mathrm{M}_{0}$ & 114 & 1706.0 & 796.7 & 0.48 & 15.05 \\
$\mathrm{~V}_{3} \mathrm{~F}_{1} \mathrm{M}_{1}$ & 113 & 1740.3 & 1033.3 & 0.59 & 15.27 \\
$\mathrm{~V}_{3} \mathrm{~F}_{2} \mathrm{M}_{0}$ & 117 & 1792.5 & 866.7 & 0.48 & 15.36 \\
$\mathrm{~V}_{3} \mathrm{~F}_{2} \mathrm{M}_{1}$ & 117 & 1810.0 & 1236.7 & 0.68 & 15.43 \\
$\mathrm{LSD}_{(0.05)}$ & $\mathrm{NS}$ & 55.59 & 103.5 & 0.032 & $\mathrm{NS}$ \\
$\mathrm{CV}_{(\%)}$ & 1.5 & 5.3 & 12.5 & 13.3 & 12.1 \\
\hline
\end{tabular}

YIELD ATTRIBUTES AND YIELD

The result showed that there was a significant change in most of the yield attributes of chickpea due to cultivars, nutrient management and mulching practices (Table 2). It has been presented that number of branches was significantly affected due to cultivars and nutrient management practices and reported that higher number of branches plant ${ }^{-1}$ was recorded in ICL-84050841 (7.85) as compared to Dhanush (7.42) and KWR-108 (3.98). The application of NPK (6.56) showed a greater effect on branches plant ${ }^{-1}$ than FYM (6.28). ICL$840508-41$ had the highest number of pods $\mathrm{m}^{-2}(65.5)$ than Dhanush (46) and KWR-108 (30.83). It has seen that application of NPK gave a higher number of pods (49.83) as compared to FYM (45.06). This was due to quick solubility and early recovery of inorganic fertilizers in soil as compared to the mulch and FYM application. Nitrogen helps plant to grow quickly, whereas phosphorus supports the formation of amino-acids, sugars and starches, while potassium assists in 
photosynthesis, fruit quality and the building of protein. The impact of mulching on number of pods was significant in all respective observations. Wang et al., (2001) and Silim et al., (1988) also found that grain yield of chickpea varied according to the amount of moisture in dry conditions and also it is lower in comparison to normal condition. Aggarwal et al., (1992) reported that high levels of moisture stored in soil depend on soil structure and reduction of evaporation by using mulch, which has been prominently matched in our experimentation too.

Table 2: Influence of cultivars, nutrient and mulching on yield of chickpeas

\begin{tabular}{lccccc}
\hline \multirow{2}{*}{ Treatment } & \multicolumn{5}{c}{ Yield attributes } \\
\cline { 2 - 6 } & $\begin{array}{c}\text { Branches } \\
\text { plant }^{-1}\end{array}$ & $\begin{array}{c}\text { Pods } \\
\mathbf{m}^{-2}\end{array}$ & $\begin{array}{c}\text { Seeds } \\
\text { pod }^{-1}\end{array}$ & $\begin{array}{c}\text { Wt. of pods } \\
\left(\mathbf{g ~ m}^{-2}\right)\end{array}$ & $\begin{array}{c}1000 \text { seed } \\
\text { wt. (g) }\end{array}$ \\
\hline Cultivars & & & & & \\
KWR- 108 & 3.98 & 30.83 & 2.66 & 34.6 & 174.2 \\
Dhanush & 7.42 & 46.00 & 2.64 & 43.2 & 141.6 \\
ICL-840508-41 & 7.85 & 65.50 & 2.33 & 49.2 & 195.8 \\
LSD (0.05) & 1.44 & 6.60 & 0.08 & 12.1 & 11.44 \\
Nutrient Management & & & & \\
FYM & 6.28 & 45.06 & 2.56 & 43.3 & 172.2 \\
NPK & 6.56 & 49.83 & 2.53 & 41.4 & 168.9 \\
LSD (0.05) & 0.081 & 1.189 & 0.06 & 1.25 & 3.52 \\
Mulching & & & & & \\
No mulch & 6.15 & 43.33 & 2.50 & 36.9 & 159.1 \\
Mulch & 6.68 & 51.56 & 2.59 & 47.7 & 181.9 \\
LSD (0.05) & NS & 3.18 & 0.04 & NS & 10.07 \\
CV (\%) & 11.2 & 13.5 & 15.7 & 14.9 & 6.3 \\
\hline
\end{tabular}

The maximum number of seeds $\operatorname{pod}^{-1}(2.66)$ was on KWR-108 than Dhanush (2.64) and ICL-840508-41 (2.33). The impact of FYM (2.56) gave higher response to the number of seeds pod $^{-1}$ than the application of NPK (2.53). Organic manures result in increased organic content leading to increased water holding capacity, increased water stable aggregation and decreased bulk density. The impact of mulch on seeds pod ${ }^{-1}$ was of greater value (2.59) than no mulch (2.53). Organic mulch served as food for many micro-organisms in the soil. These organisms are necessary for maintaining bio-chemical processes and promoting soil granulation. Mulch also helps to keep the soil temperature 
constant so that the activity of the micro-organisms can continue at even rate. The weight of pods of ICL-840508-41 was higher $\left(49.2 \mathrm{~g} \mathrm{~m}^{-2}\right)$ than of Dhanush $\left(43.2 \mathrm{~g} \mathrm{~m}^{-2}\right)$ and KWR-108 $\left(34.6 \mathrm{~g} \mathrm{~m}^{-2}\right)$ cultivars. There was a significant difference on 1000 seed weight due to cultivars. The effect of FYM on 1000 seed weight of chickpea was significantly superior to the effect of NPK. The impact of mulching was also significantly higher than of no mulch.

Table 3: Influenced of cultivars, nutrients and mulching upon chickpea yield

\begin{tabular}{|c|c|c|c|c|c|c|c|}
\hline \multicolumn{8}{|c|}{ Seed yield $\left(\mathrm{kg} \mathrm{ha}^{-1}\right)$} \\
\hline Treatment & FYM & NPK & Mean & Treatment & $\begin{array}{l}\text { No- } \\
\text { mulch }\end{array}$ & Mulch & Mean \\
\hline KWR-108 & 383.0 & 515.0 & 449.0 & FYM & 549.0 & 717.0 & 633.0 \\
\hline Dhanush & 600.0 & 1002.0 & 801.0 & NPK & 689.0 & 1023.0 & 856.0 \\
\hline ICL-840508- & 915.0 & 1052.0 & 983.5 & & & & \\
\hline 41 & & & & Mean & 619.0 & 870.0 & \\
\hline \multirow[t]{2}{*}{ Mean } & 632.7 & 856.3 & & & & & \\
\hline & & & & LSD (0.05) & 99.61 & & \\
\hline LSD (0.05) & 103.5 & & & & & & \\
\hline
\end{tabular}

The regression equation and correlation between seed yield of chickpea with its yield attributes viz plants ${ }^{-2}$, pods $\mathrm{m}^{-2}$, weight of pods ${ }^{-2}$ and test weight showed the positive co-relations with the $R^{2}$ values of $0.05,0.21,0.09$ and 0.71 , respectively, showing the better contribution of chickpea yield with pods $\mathrm{m}^{-2}$ and test weight.

The interaction effect of chickpea due to cultivar and nutrient management, and nutrient management and mulching were found to be significant (Table 3 ). It is resulted that seed yield of chickpea obtained with ICL-840508-41 under NPK (1052 kg ha-1) was significantly superior to the seed yield obtained with FYM $\left(915.0 \mathrm{~kg} \mathrm{ha}^{-1}\right)$, but was found to be statistically at par with Dhanush with NPK (1002.0 kg ha-1). The least yield of chickpea was recorded for chickpea cultivar KWR-108 with the application of FYM $\left(383.0 \mathrm{~kg} \mathrm{ha}^{-1}\right)$. Similarly, the higher seed yield of chickpea was recorded under NPK with mulch $(1023.0 \mathrm{~kg}$ $\left.\mathrm{ha}^{-1}\right)$, followed by FYM with mulch $\left(717.0 \mathrm{~kg} \mathrm{ha}^{-1}\right)$ and the least ( $\left.549.0 \mathrm{~kg} \mathrm{ha}^{-1}\right)$ with FYM and no-mulch (Table 3). From the mean data it was reported that chickpea yield was significantly superior on the application of NPK fertilizer over FYM application. This might be due to quick solubility and release of nutrients form the application of NPK fertilizer. On an average, application of 
mulch along with NPK application was found to be better for chickpea production in comparison to no mulch. Balanced fertilization and mulching has become a valuable climate change adaptation measures for increasing grain production in areas characterized by low air temperature and rainfall.

\section{PROFITABILITY OF THE CHICKPEA}

The highest total cost of cultivation was taken for improved chickpea cultivars (KWR -108-NRs $36951 \mathrm{ha}^{-1}$, and ICL-840508-41- NRs $36871 \mathrm{ha}^{-1}$ ), while it was low for Dhanush (NRs 31871 ha $^{-1}$ ) due the less cost of Dhanush as local Desi type species, the former two were Kabulian type. The cost for cultivation due to NPK fertilizer (NRs 31951 ha- $^{-1}$ ) and mulch was higher due to added price of fertilizer and paddy straw (Table 4). Net return represents the actual profitability of the system after deduction of cultivation cost from the gross returns of the system. The chickpea cultivars showed the clear and distinct difference in the net returns of the system. The average net returndue to cultivars was found to be NRs $69084 \mathrm{ha}^{-1}$. The chickpea cultivar ICL-840508-41 was found significantly superior regarding the net return to the KWR-108 and Dhanush cultivars (Table 4). Chickpea cultivars grown with mulch had also significantly higher gross returns than that of no mulch. Chickpea with mulching exhibited significantly higher net returns (NRs $118639 \mathrm{ha}^{-1}$ ) than that of no mulch. Any value of B: $C$ ratio greater than 2 is considered safe as the farmer get NRs 2.00 for every rupee invested (Reddy and Reddi, 2009). On the other hand, minimum B: $\mathrm{C}$ ratio of 1.5 for the agricultural sector has been fixed for any enterprises to be economically viable. Therefore, any crop enterprise must maintain a $1.5 \mathrm{~B}: \mathrm{C}$ ratio to be economically sustainable (Ali Masood et al., 2002). There was significant role of chickpea cultivars in determination of $B: C$ ratio of the system. Clearly, ICL-840508-41 cultivar gave significantly higher B:C ratio than that of KWR-108 and Dhanush cultivars. The chickpea cultivar ICL-840508-41 with mulch was found with the best $B: C$ ratio than that of other combinations. This combination had higher $B$ : $C$ ratio because of the higher grain yield of chickpea cultivar and higher market price of the produce. 
The Journal of Agriculture and Environment Volume: 20, June, 2019

Table 4: Influenced of cultivars, nutrient and mulching on economic analysis of chickpea

\begin{tabular}{|c|c|c|c|c|}
\hline \multirow[b]{2}{*}{ Treatment } & \multicolumn{4}{|c|}{ Economics (NRs ha-1) } \\
\hline & $\begin{array}{l}\text { Total cost of } \\
\text { cultivation }\end{array}$ & Gross return & $\begin{array}{c}\text { Net } \\
\text { return }\end{array}$ & $\mathrm{B} / \mathrm{C}$ ratio \\
\hline \multicolumn{5}{|l|}{$\underline{\text { Cultivars }}$} \\
\hline KWR-108 & 36951 & 108312 & 73902 & 3.14 \\
\hline Dhanush & 31871 & 65000 & 30589 & 1.87 \\
\hline ICL-840508-41 & 36871 & 137171 & 102760 & 3.97 \\
\hline $\operatorname{LSD}(0.05)$ & - & 2636.8 & 2271.3 & 0.077 \\
\hline \multicolumn{5}{|c|}{ Nutrient Management } \\
\hline$F Y M$ & 31871 & 90222 & 55851 & 2.62 \\
\hline NPK & 32951 & 116767 & 82316 & 3.37 \\
\hline $\operatorname{LSD}(0.05)$ & - & 1014.9 & 828.7 & 0.029 \\
\hline \multicolumn{5}{|l|}{ Mulching } \\
\hline No mulch & 31871 & 88350 & 56439 & 2.77 \\
\hline Mulch & 36951 & 118639 & 81728 & 3.21 \\
\hline LSD (0.05) & - & NS & 2749.5 & 0.076 \\
\hline CV (\%) & - & 8.2 & 12.3 & 8.3 \\
\hline
\end{tabular}

\section{CONCLUSION}

It was observed that drought tolerant improved chickpea cultivar ICL-84050841 was more efficient than Dhanush and KWR-108 to show stable heat use efficiency at late planted conditions of central terai. Heat use efficiency of the cultivar ICL-840508-41 was significantly higher and stable (0.68) with NPK and mulching followed by other treatments indicating the superiority of the mulching with drought tolerant variety than the deshi type Dhanush. Under late planting, chickpea cultivars are grown by adopting climate change measures like balanced fertilization and mulching. Chickpea grown with mulch emerged with significantly higher $\mathrm{B}$ : $\mathrm{C}$ ratio than that grown without mulch. Application of paddy straw mulch along with NPK fertilizer was greater than the effect of FYM nutrient in augmenting the productivity and profitably of chickpea. 


\section{ACKNOWLEDGEMENT}

United Nations Development Program (UNDP) is cordially thanked for providing the financial research support. NGLRP Kajura, Banke is highly acknowledged for the support in providing seed materials. Post-graduate program of IAAS Kirtipur is very much thanked for their kind help providing during the experimentation period.

\section{REFRENCES}

Aggarwal, P., Bhardmaj S. P. and Khullar, A. K. 1992. Appropriate tillage systems for rainfed wheat in Doon valley. Indian J. Agronomy. 21:116-173.

Ali, Masood, Ganeshs murthy, A.N. and Srinivasan Rao, Ch. 2002. Role of pulses in soil health and sustainable crop production. Indian Journal of Pulse Research.15,2:107-117.

Amgain, L.P. 2013. Conservation agriculture practices for increasing resource-use efficiency and productivity of rainfed cropping systems. Ph. D Thesis (Unpublished). Agronomy Division. IARI, Pusa, New Delhi.

Bishnoi, O. P., Singh, S. and Niwas, R. 1995. Effect of temperature on phenological development of wheat (Triticum aestivum L.) crop in different row orientations. Indian J.Agric. Sci. 65:211-214.

Daniel, T. 2015. Chickpea and temperature stress. Proceedings of Environment and Plant Breeding. The University of Sydney. Australia.

Dhakal, S.2013. Performance of legume and non-legume intercropped maize cultivars in foot-hills of Nepal. M Sc Ag thesis (unpublished). Tribhuwan University. Institute of Agriculture and Animal Science. Kirtipur. Kathmandu. Nepal.

Dhyani, S. K., Newaj, R. and Sharma. A. R. 2009. Agroforestry: its relation with agronomy, challenges and opportunities. Indian Journal of Agronomy. 54 (3): 259-266.

FAO. 2015. Impact of climate change on agriculture in Asia and the Pacific. Beijing. China. May 17- 21, 2014.

Ghosh, D.C., Nandi, P. and De, B.2000. Phenological development and productivity of wheat (Triticum aestivum L.) at different dates of sowing. Indian J. Agric. Sci. 70, 6:390-395.

Gill, M.S. and Ahlawat, I.P.S. 2006. Crop diversification - its role towards sustainability and profitability. Indian Journal of Fertilizers.2,9:125-138.

Gomez, K.A. and Gomez, A.A. 1984. Statistical procedures for agricultural research. The International Rice Research Institute. Los Banos. Laguna. Philippines. 
Hoffmann, U. 2013. Agriculture - a key driver and a major victim of global warming. Lead Article 1:3-5.

Khanna-Chopra, R. and Sinha, S. K. 1987. Chickpea: Physiological aspects of growth and yield. The Chickpea.1:163-189.

Lal, M., Bhati, D. S. and Nag, A. K. 2004. Economics and production potential of different cropping sequence on farmers' field. Journal of Eco-Physiology.7,3/4:143145.

MoAD. 2014. Statistical information on Nepalese Agriculture. Singha Durbar, Kathmandu, Ministry of Agriculture and Development.

NGLRP. 2015. Annual Report. Nepal Agriculture Research Council; National Grain Legume Research Program, Rampur, Chitwan.

NGLRP. 2018. Annual Report. Nepal Agriculture Research Council; National Grain Legume Research Program, Khajura, Nepalgunj, Banke.

NMRP. 2015. Annual Report. Nepal Agriculture Research Council; National Maize Research Program, Rampur, Chitwan.

Pathak, H., Bhatia, A., Prasad, S., Singh, S., Kumar, S., Jain, M.C. and Kumar, U. 2002. Emission of nitrous oxide from rice-wheat systems of Indo-Gangetic Plains of India. Environmental Monitoring Assessment. 77:163-178.

Paudel, M.N. 1995. Nutrient management for Sulphanburi- 90 rice variety in acid sulfate soil with green leaf manure. M.Sc. Thesis (unpublished). Asian Institute of Technology, Bangkok. Thailand.

Pokhrel, A., Aryal, L. and Poudel, P. P. 2018. A review on research work of Grain-legume Research Program, Nepal Agriculture Research Council.GoN/NARC/NGLRP, Khajura, Nepalgunj, Banke.pp 1-49.

Rajput, R. P. 1980. Response of soybean crop to climatic and soil environments. Ph. D. Thesis (unpublished), IARI, Pusa, New Delhi, India.

Rajput, R. P. and Paradkar, V. K. 1987. Accumulated heat units and phenology relationships in wheat (Triticum aestivum L.) as influenced by planting dates under late sown conditions.J Agron.\& Crop Sci. 159: 345-348.

Rathore, A.L., Pal, A.R. and Sahu, K.K. 1998. Tillage and mulching effects on water use, root growth and yield of rainfed mustard and chickpea grown after lowland rice. Journal of the Science of Food and Agriculture.78, 2:149-161.

Reddy, T. Y. and Reddi.G. H. 2009. Agronomy of Field Crops. Kalyani Publishers, Third Revised Edition. Kalyani Publishers, Ludhiana, India. pp. 9-124. 
Ritchie, J.T. and Nesmith, D.S. 1991. Temperatures and crop development. Modeling plant and soil systems. Agronomy Monograph No. 31, ASA-CSSA-SSSA, Madison, WI53711, USA.

Sikder, S. 2009. Accumulated heat unit and phenology of wheat cultivars as influenced by late sowing heat stress condition. J Agric Rural Dev. 7,1\&2: 57-64.

Silim, S. N., Saxena, M. C. and Singh, K.B. 1988. Evaluation of spring sown chickpea for drought tolerance. Annual Report.ICARDA. Aleppo. Syria

Sreenevas, G., Devender, M., Reddy, Raji, D. and Reddy T. S. 2010. Agro-meteorological indices in relation to phenology of aerobic rice. Journal of Agrometeorology.12, 2:241-244.

Summerfield, R. J., Ellis R. H. and. Roberts, E. H. 1989. Vernalization in chickpea (Cicer arietinum). Field Crops Res.12:599- 603.

Vaidya, V.B., Varshneya, M.C., Bote, N.L. and Naidu, J.R.V. 1995. Estimation of thermal efficiency and apparent reflectivity of mulches using soil temperature. Journal of Mahrashta Agricultural Universities.20,3:341-344.

Wang, H. X., Zhang, L., Dawes, W.R and Liu, C. M. 2001. Improving water use efficiency of irrigated crops in the North China plain Agric. Water Management. 22:151167. 